\title{
Kontrol Positif Sintetik untuk Deteksi Penyakit Mulut dan Kuku dengan Reverse-Transcriptase Polymerase Chain Reaction
}

\section{(Synthetic Positive Control for Detection of Foot and Mouth Disease by Reverse- Transcriptase Polymerase Chain Reaction)}

\author{
Nuradji $\mathrm{H}^{1}$, Wiyono A ${ }^{1}$, Daulay RSD ${ }^{2}$, Rochmah A ${ }^{2}$ \\ ${ }^{1}$ Balai Besar Penelitian Veteriner, Jl. RE Martadinata No. 30, Bogor 16114 \\ ${ }^{2}$ Pusat Veterinaria Farma, Surabaya \\ harimurti.nuradji@gmail.com
}

\begin{abstract}
Foot and Mouth Disease (FMD) is strategic contagius animal disease and still excotic in Indonesia. To anticipate the disease is required a quick and accurate diagnostic test. RT-PCR is a diagnostic test which is recommended by World Animal Health Organization (OIE) to detect this disease. Nevertheless, this test needs positive control in each test. The aim of this study was to develop synthetic positive control to detect FMD by using RT-PCR. Synthetic positive control was designed based on the recommended primers. The new developed synthetic positive controls was tested by RT-PCR and was compared with the positive controls extracted from inactivated antigen used for ELISA AB coating. Results showed that syntethic positive control developed generated better results compared to positive control extracted from inactivated antigen. This suggests that the new synthetic positive control developed in this study can be used for RT-PCR test for the detection of FMD in Indonesia.
\end{abstract}

Key Words: Synthetic Positive Control, FMD, RT-PCR

\begin{abstract}
ABSTRAK
Penyakit Mulut dan Kuku merupakan penyakit hewan menular strategis dan masih eksotik di Indonesia. Untuk mengantisipasi penyakit ini diperlukan deteksi penyakit yang cepat dan akurat. Uji RT-PCR merupakan salah satu uji yang direkomendasikan untuk deteksi penyakit ini. Namun demikian, uji ini memerlukan kontrol positif yang dapat digunakan dalam setiap pengujian. Tujuan dari penelitian ini adalah mengembangkan sintetik kontrol positif untuk deteksi penyakit PMK dengan uji RT-PCR. Kontrol positif didisain berdasarkan primer yang direkomendasikan Organisasi Kesehatan Hewan Dunia (OIE). Kontrol positif kemudian diuji dengan uji RT-PCR dan dibandingkan dengan kontrol positif yang diperoleh dari antigen inaktif yang digunakan dalam uji ELISA. Hasil menunjukkan bahwa sintetik kontrol positif yang dikembangkan memberikan hasil yang yang lebih baik dibandingkan dengan kontrol positif yang diekstraksi dari antigen inaktif. Hal ini menunjukkan bahwa kontrol positif sintetik ini dapat digunakan dalam pengujian RT-PCR untuk mendeteksi PMK di Indonesia.
\end{abstract}

Kata Kunci: Kontrol Positif Sintetik, PMK, RT-PCR

\section{PENDAHULUAN}

Penyakit Mulut dan Kuku (PMK) adalah salah satu penyakit eksotik di Indonesia (Kementerian Pertanian 2013). Penyakit ini disebabkan oleh virus dari genus Aphthovirus yang merupakan virus yang berjangkit di sebagian besar belahan dunia, seringkali menyebabkan epidemi yang luas pada sapi dan babi piaraan (Grubman \& Baxt 2004). Penyakit ini biasanya sangat menular dan merugikan pada semua hewan berkuku belah (Grubman \& Baxt 2004; Wernery \& Kinne 2012; Jamal \& Belsham 2013). Penyakit ini disebabkan oleh virus dari genus aphthovirus, dari famili Picornaviridae (Grubman \& 
Baxt 2004; OIE 2012; Jamal \& Belsham 2013). Sampai saat ini terdapat tujuh serotipe virus PMK yaitu: O, A, C, Asia 1, SAT 1, SAT 2 dan SAT 3 yang dilaporkan (Grubman \& Baxt 2004; OIE 2012; Jamal \& Belsham 2013) meskipun secara klinis akan sulit dibedakan.

Hewan berkuku belah seperti sapi, babi, kambing, domba, kerbau dan beberapa hewan liar seperti rusa, antelope dan babi hutan juga dapat terinfeksi oleh virus PMK (Grubman \& Baxt 2004; OIE 2012). Meskipun tidak menyebabkan kematian yang tinggi pada hewan dewasa, penyakit ini menyebabkan gejala klinis yang bervariasi tergantung galur virus PMK yang menyerang (Grubman \& Baxt 2004). Gejala klinis yang pertama muncul adalah kenaikan suhu tubuh diikuti lemas, nafsu makan turun, pada saat lepuh-lepuh terbentuk di dalam mulut, salivasi akan meningkat dan disertai terbentuknya busa di sekitar bibir serta leleran saliva yang menggantung (Grubman \& Baxt 2004; Jamal \& Belsham 2013).

Di Indonesia, kejadian PMK pertama kali dilaporkan pada tahun 1887 di Malang. Penyakit ini kemudian menyebar ke Sumatera, Jawa, Sulawesi, Kalimantan, Bali dan Nusa Tenggara (Soehadji \& Setyaningsih 1994). Pada tahun1962 penyakit PMK dilaporkan di Bali akibat masuknya ternak secara ilegal dari Jawa Timur dan kasus berhenti pada tahun 1966. Wabah penyakit PMK kembali dilaporkan pada tahun 1983 di Jawa Tengah dan Jawa Timur dan dalam waktu 2 minggu telah menyebar ke seluruh Pulau Jawa melalui perpindahan ternak dan perdagangan daging. Untuk mengendalikan penyakit PMK tersebut ditempuh denegan dua cara yaitu dengan melakukan vaksinasi masal terhadap hewan yang rentan dan mengontrol jalur perpindahan hewan serta produk asal hewan terutama yang berasal dari daerah tertular. Vaksinasi dilakukan pada lebih dari 95\% ternak yang diduga terserang PMK di Pulau Jawa. Kegiatan pengendalian ini dapat menurunkan jumlah kasus PMK yang terjadi di Indonesia dari tahun 1974 sampai dengan tahun1983. Pembebasan penyakit ini di Indonesia diawali dengan status bebas di Bali pada tahun 1978, Jawa Timur pada tahun 1981, dan Sulawesi Selatan pada tahun 1983. Indonesia dinyatakan bebas penyakit PMK pada tahun 1986 (Soehadji \& Setyaningsih 1994).

Ada beberapa pengujian yang digunakan untuk mendeteksi PMK baik itu isolasi virus, serologi atau molekuler dengan PCR (Reid et al. 2000; Grubman \& Baxt 2004; Ma et al. 2011; OIE 2012; Chen et al. 2013). Dibandingkan dengan isolasi virus, deteksi secara molekuler dapat dilakukan lebih cepat dan dapat mengurangi risiko penyebaran virus karena kesalahan yang terjadi di laboratorium. Hal ini dikarenakan ekstraksi sampel pada uji PCR menggunakan reagen berbahan dasar detergen yang akan menginaktivasi virus. Dibandingkan dengan isolasi virus, PCR lebih mahal dan memerlukan kontrol positif pada setiap ujinya. PMK merupakan penyakit hewan strategis dan masih dinyatakan bebas di Indonesia, pengadaan kontrol positif merupakan suatu kendala karena harus mendatangkan antigen dari luar negeri. Sintetik kontrol positif sudah digunakan dan dikembangkan untuk beberapa uji penyakit (Smith et al. 2006; Caasi et al. 2013). Tujuan penelitian ini adalah mengembangkan kontrol positif sintetik yang digunakan dalam pengujian untuk mendeteksi PMK di Indonesia. Kontrol positif tersebut dikembangkan dengan mengacu pada primer untuk uji RT-PCR yang direkomendasikan dari World Animal Health Organization (OIE)(OIE 2012).

\section{MATERI DAN METODE}

\section{Sequence primer}

Sequence primer yang digunakan dalam pengembangan sintetik kontrol positif dalam penelitian ini mengikuti primer dari World Animal Health Organization (OIE)(OIE 2012) dan penelitian sebelumnya (Reid et al. 2000; Lung et al. 2011). 


\section{Kontrol positif}

Kontrol positif sintetik yang digunakan dalam penelitian ini adalah double stranded DNA molekul dengan panjang sekitar 328 bp yang disintesis dengan gBlocks Gene Fragments. Kontrol positif sintetik tersebut diverifikasi sebelum digunakan. Kontrol positif yang digunakan sebagai pembanding adalah kontrol positif yang diekstraksi dari antigen inaktif yang digunakan dalam uji ELISA. Kontrol positif antigen inaktif tersebut diperoleh dari Pusat Veterinaria Farma (Pusvetma), Surabaya. Kontrol positif yang digunakan adalah Antigen PMK serotipe A, O, C dan Asia 1. Kontrol positif sintetik yang digunakan dioptimasi dengan uji Gradient RT-PCR dengan 6 suhu annealing yang berbeda. Setelah ditetapkan suhu annealing kemudian kontrol positif sintetik yang telah didilusi dengan konsentrasi 1:10, 1:100 dan 1:1000 diuji dengan uji RT-PCR dibandingkan dengan kontrol positif dari antigen inaktif.

\section{Ekstraksi total RNA}

Total RNA diekstraksi menggunakan geneaid total RNA extraction kit (Geneaid Biotech Ltd., Taiwan) sesuai dengan petunjuk yang ada. Secara singkat, 0,2 ml inactivated antigen ditambahkan ke dalam microfuge tube $0,5 \mathrm{ml}$ yang berisi alkohol $70 \%$ dan $4 \mu \mathrm{l}$ betamercapto ethanol. Sampel kemudian ditambahkan ke dalam reagen Geneaid, dicuci dan RNA dielusi menggunakan $50 \mu 1$ RNAse free water.

\section{Reverse trancriptase polymerase chain reaction (RT-PCR)}

Uji RT-PCR dilakukan dengan mengikuti prosedur dari Verso 1-Step RT-PCR HotStart Kit (Thermo Fisher Scientific, Inc). Secara singkat, $3 \mu 1$ RNA virus digunakan sebagai template dalam $20 \mu \mathrm{l}$ pereaksi yang mengandung Verso Enzyme Mix, 2X 1-Step PCR Hot-Start Master Mix, RT Enhancer, Primer dan Nuclease Free Water. Primer yang digunakan mengikuti primer dari OIE (2012) dan penelitian sebelumnya (Reid et al. 2000; Lung et al. 2011) seperti terlihat pada Tabel 1.

Tabel 1. Nama, sequence, spesifisitas dan ukuran produk RT-PCR dari primer untuk deteksi PMK yang digunakan dalam penelitian ini

\begin{tabular}{|c|c|c|c|c|}
\hline Primer & Sequence 5'-3' & $\begin{array}{l}\text { Spesifisitas } \\
\text { terhadap virus } \\
\text { PMK }\end{array}$ & $\begin{array}{l}\text { Ukuran } \\
\text { produk RT- } \\
\text { PCR (bp) }\end{array}$ & Sumber \\
\hline $1 \mathrm{~F}$ & GCCTGGTCTTTCCAGGTCT & Semua serotipe & 328 & \multirow{2}{*}{$\begin{array}{l}\text { Reid et al. (2000); } \\
\text { Lung et al. (2011); } \\
\text { OIE (2012) }\end{array}$} \\
\hline $1 \mathrm{R}$ & CCAGTCCCCTTCTAGATC & Semua serotipe & 328 & \\
\hline
\end{tabular}

Sintesis $c$ DNA untuk gradient RT-PCR dilakukan dengan inkubasi pada suhu $48^{\circ} \mathrm{C}$ selama 30 menit, diikuti dengan inaktivasi verso pada suhu $94^{\circ} \mathrm{C}$ selama 10 menit. PCR dilakukan dengan 35 siklus yang meliputi: denaturation $\left(94^{\circ} \mathrm{C}\right.$ selama 1 menit), enam suhu annealing digunakan dalam uji gradient $\mathrm{RT}$-PCR $\left(50^{\circ} \mathrm{C} ; 51,1^{\circ} \mathrm{C} ; 54^{\circ} \mathrm{C} ; 55^{\circ} \mathrm{C} ; 56,5^{\circ} \mathrm{C}\right.$ dan $57^{\circ} \mathrm{C}$ selama 1 menit), extention $\left(72^{\circ} \mathrm{C}\right.$ selama 2 menit). Final extention dilakukan pada suhu $72^{\circ} \mathrm{C}$ selama 7 menit.

Sintesa $c$ DNA untuk RT-PCR dilakukan dengan inkubasi pada suhu $48^{\circ} \mathrm{C}$ selama 30 menit, diikuti dengan inaktivasi verso pada suhu $94^{\circ} \mathrm{C}$ selama 10 menit. PCR dilakukan dengan 35 siklus yang meliputi: denaturation $\left(94^{\circ} \mathrm{C}\right.$ selama 1 menit), annealing $\left(55^{\circ} \mathrm{C}\right.$ 
selama 1 menit), extention $\left(72^{\circ} \mathrm{C}\right.$ selama 2 menit). Final extention dilakukan pada suhu $72^{\circ} \mathrm{C}$ selama 7 menit.

Analisis produk RT-PCR dilakukan dengan elektroforesis menggunakan $5 \mu \mathrm{l}$ produk PCR pada $100 \mathrm{~V}$ selama 1 jam pada agarose $1,5 \%$ dalam $1 \times$ tris buffer. Visualisasi dilakukan dengan pewarnaan menggunakan ethidium bromide dan transluminator ultraviolet.

\section{HASIL DAN PEMBAHASAN}

Penyakit Mulut dan Kuku (PMK) merupakan penyakit yang sangat menular dan menyebabkan kerugian ekonomi yang sangat besar. Deteksi penyakit secara dini merupakan salah satu strategi dalam mencegah penyakit ini masuk ke Indonesia. Pada penelitian ini kontrol positif sintetik dikembangkan untuk digunakan dalam uji RT-PCR.

Seperti terlihat pada Gambar 1 kontrol positif sintetik dan primer yang digunakan memberikan hasil yang bagus ditandai dengan pita yang jelas pada $328 \mathrm{bp}$, terutama pada suhu annealing $50^{\circ} \mathrm{C} ; 51,1^{\circ} \mathrm{C} ; 54^{\circ} \mathrm{C} ; 55^{\circ} \mathrm{C} ; 56,5^{\circ} \mathrm{C}$, sedangkan pada suhu annealing $57^{\circ} \mathrm{C}$ pita terlihat lebih samar.

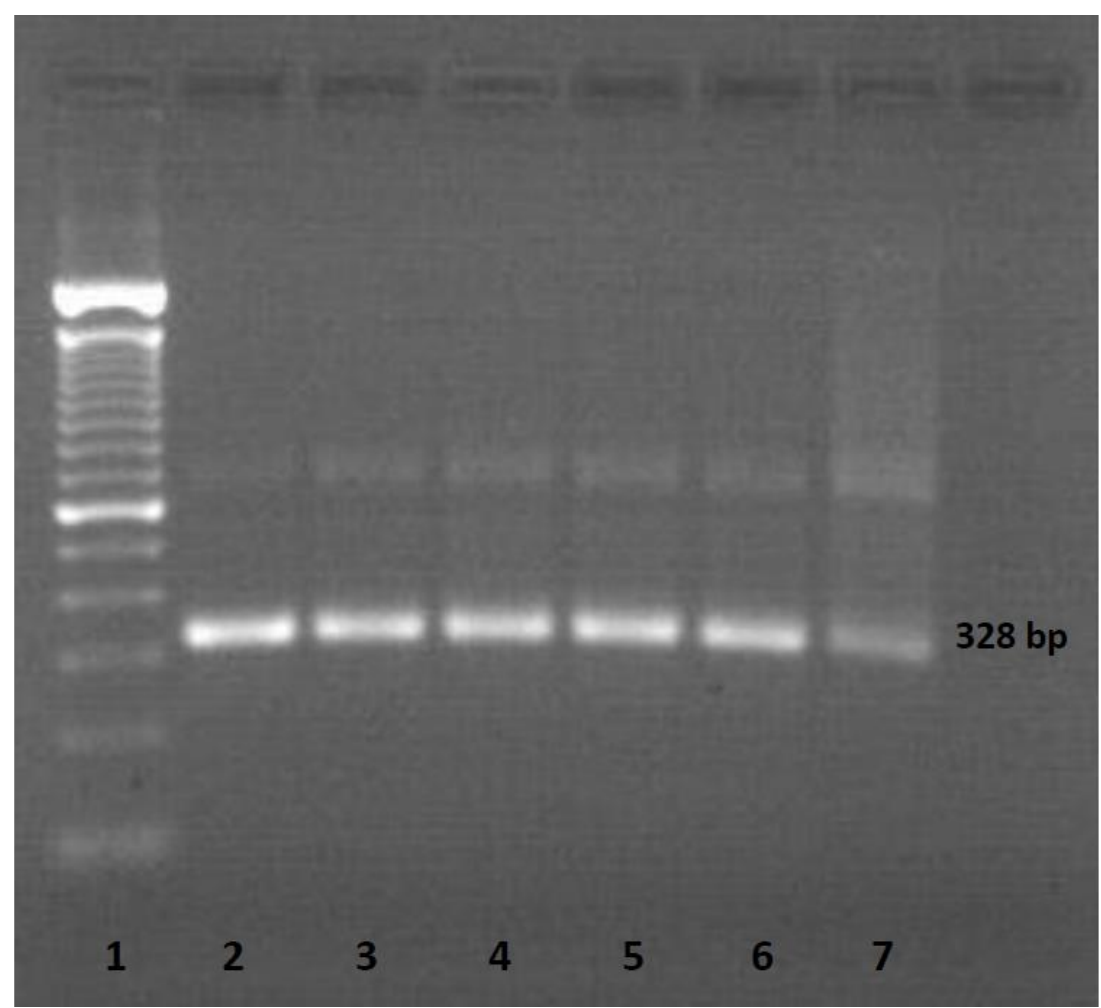

1: DNA marker; 2: Annealing pada suhu $50^{\circ} \mathrm{C}, 3: 51,1^{\circ} \mathrm{C} ; 4: 54^{\circ} \mathrm{C} ; 5: 55^{\circ} \mathrm{C} ; 6: 56,5^{\circ} \mathrm{C} ; 7: 57^{\circ} \mathrm{C}$

Gambar 1. Analisis produk gradient RT-PCR sintetik kontrol positif menggunakan gel electrophoresis

Hal ini sesuai dengan penelitian sebelumnya yang menunjukkan bahwa primer yang digunakan dalam uji RT-PCR ini (Primer 1F dan 1R) memberikan ukuran produk $328 \mathrm{bp}$ (Reid et al. 2000; Ahmed et al. 2012; OIE 2012; Kandeil et al. 2013; Habib et al. 2014; Nandi et al. 2015). Primer $1 F$ dan 1R banyak digunakan untuk mendeteksi virus PMK secara umum. Penelitian sebelumnya menunjukkan bahwa primer ini dapat mendeteksi virus PMK dari serotipe A, O, C, Asia 1 dan SAT 1, 2 dan 3 (Reid et al. 2000; Reid et al. 2002). Selain itu, suhu annealing yang biasa digunakan adalah $55^{\circ} \mathrm{C}$ selama 30 detik (Reid 
et al. 2000) yang menujukkan hasil yang sama pada penelitian ini dengan suhu annealing $55^{\circ} \mathrm{C}$. Namun demikian, terlihat pada Gambar 1 bahwa suhu annealing $50^{\circ} \mathrm{C} ; 51,1^{\circ} \mathrm{C}$; $54^{\circ} \mathrm{C}$; dan $56,5^{\circ} \mathrm{C}$ memberikan hasil yang sama dan dapat digunakan dalam uji RT-PCR dengan menggunakan primer dan kontrol positif sintetik yang digunakan dalam penelitian ini. Suhu annealing dalam uji RT-PCR untuk PMK sangat penting, karena peningkatan suhu kecil dapat merubah sensitivitas dari RT-PCR untuk mendeteksi virus PMK serotipe A, O, C, Asia 1 dan SAT 1, 2, 3 (Reid et al. 1999).

Untuk menganalisis hasil RT-PCR sintetik kontrol positif, produk yang dihasilkan dievaluasi menggunakan gel electroforesis seperti terlihat pada Gambar 2. Hasil menunjukkan bahwa kontrol positif sintetik dengan konsentrasi 1:10, 1:100 dan 1:1.000 memberikan hasil yang bagus dengan menunjukkan pita yang jelas pada $328 \mathrm{bp}$. Sementara itu pada kontrol positif yang diekstraksi dari antigen inaktif PMK serotipe A dan O memberikan pita yang lebih tipis. Sedangkan kontrol positif antigen inaktif PMK serotipe $\mathrm{C}$ dan Asia 1 menunjukkan pita yang sangat tipis. Sementara kontrol negatif tidak menunjukkan hasil amplifikasi produk. Hasil ini sesuai dengan penelitian sebelumnya dengan primer yang sama, dimana produk yang dihasilkan terlihat sekitar 328 bp (Reid et al. 2000). Perbedaan pita yang terlihat mungkin disebabkan proses inaktivasi antigen PMK yang dapat mempengaruhi struktur viron PMK. Selain itu, proses siklus PCR juga dapat mempengaruhi hasil yang diperoleh, seperti peningkatan suhu annealing (Reid et al. 1999).



1: SKP 1:10; 2: SKP 1:100; 3: SKP 1:1.000; 4: DNA marker; 5: KP PMK serotipe A; 6: KP PMK serotipe O; 7: KP PMK serotipe C; 8: KP PMK serotipe Asia 1; 9: Negatif kontrol

Gambar 2. Analisis produk RT-PCR dari sintetik kontrol positif (SKP) dan kontrol positif (KP) dari antigen inaktif menggunakan gel electrophoresis

Selain itu, hasil ini juga menunjukkan bahwa kontrol positif sintetik yang dikembangkan baik pada konsentrasi 1:10, 1:100 dan 1:1.000 memberikan pita yang lebih jelas dibandingkan dengan kontrol positif yang diekstraksi dari antigen PMK inaktif baik dari serotipe A, O, C dan Asia 1. Hal ini menunjukkan bahwa sintetik kontrol positif yang digunakan dapat digunakan sebagai alternatif kontrol positif untuk pengujian PMK dengan menggunakan RT-PCR. 


\section{KESIMPULAN}

Kontrol positif sintetik yang dikembangkan dalam penelitian ini dapat digunakan dalam uji RT-PCR dengan memberikan hasil yang lebih baik dibandingkan dengan kontrol positif yang diekstraksi dari antigen PMK inaktif baik serotipe A, O, C dan Asia 1.

\section{DAFTAR PUSTAKA}

Ahmed HA, Salem SAH, Habashi AR, Arafa AA, Aggour MGA, Salem GH, Gaber AS, Selem O, Abdelkader SH, Knowles NJ. 2012. Emergence of foot and mouth disease virus SAT 2 in Egypt during 2012. Transbound Emerg Dis. 59:476-481.

Caasi DRJ, Arif M, Payton M, Melcher U, Winder L, Ochoa-Corona FM. 2013. A multi-target, non-infectious and clonable artificial positive control for routine PCR-based assays. J Microbiol Methods. 95:229-234.

Chen H, Peng Y, Zhang Y, Liu X. 2013. Detection of foot and mouth disease Serotype O by ELISA using a monoclonal antibody. Monoclon Antib Immunodiagn Immunother. 32:47-49.

Grubman MJ, Baxt B. 2004. Foot and mouth disease. Clin Microbiol Rev [Internet]. 17:465-93. available at https://www.ncbi.nlm.nih.gov/pubmed/15084510.

Habib M, Shah MS, Muzammil HM, Manzoor S, Khan RSA, Munir R, Rajput ZI, Farooq U. 2014. Investigations of foot and mouth disease outbreaks in Faisalabad District of Punjab, Pakistan during the Year 2013. Life. 12:165-169.

Jamal SM, Belsham GJ. 2013. Foot and mouth disease: past, present and future. Vet Res. 44:1-14.

Kandeil A, El-Shesheny R, Kayali G, Moatasim Y, Bagato O, Darwish M, Gaffar A, Younes A, Farag T, Kutkat MA. 2013. Characterization of the recent outbreak of foot-and-mouth disease virus serotype SAT2 in Egypt. Arch Virol. 158:619-627.

Kementerian Pertanian. 2013. Keputusan Menteri Pertanian tentang penetapan penyakit hewan menular strategis. Jakarta (Indonesia): Kementerian Pertanian.

Lung O, Fisher M, Beeston A, Hughes KB, Clavijo A, Goolia M, Pasick J, Mauro W, Deregt D. 2011. Multiplex RT-PCR detection and microarray typing of vesicular disease viruses. J Virol Methods. 175:236-245.

Ma L, Zhang J, Chen H, Zhou J, Ding Y, Liu Y. 2011. An overview on ELISA techniques for FMD. Virol J. 8:419.

Nandi SP, Rahman MZ, Momtaz S, Sultana M, Hossain MA. 2015. Emergence and distribution of foot and mouth disease virus serotype $\mathrm{A}$ and $\mathrm{O}$ in Bangladesh. Transbound Emerg Dis. 62:328-331.

OIE. 2012. Foot and mouth disease. Terr Anim Heal Code.:1-26. [Internet]. Available from: http://www.oie.int/en/international-standard-setting/terrestrial-code/access-

online/?htmfile=sommaire.htm.

Reid SM, Ferris NP, Hutchings GH, Samuel AR, Knowles NJ. 2000. Primary diagnosis of footand-mouth disease by reverse transcription polymerase chain reaction. J Virol Methods. 89:167-176.

Reid SM, Ferris NP, Hutchings GH, Zhang Z, Belsham GJ, Alexandersen S. 2002. Detection of all seven serotypes of foot and mouth disease virus by real-time, fluorogenic reverse transcription polymerase chain reaction assay. J Virol Methods. 105:67-80.

Reid SM, Hutchings GH, Ferris NP, De Clercq K. 1999. Diagnosis of foot and mouth disease by RT-PCR: evaluation of primers for serotypic characterisation of viral RNA in clinical samples. J Virol Methods. 83:113-123. 
Smith G, Smith I, Harrower B, Warrilow D, Bletchly C. 2006. A simple method for preparing synthetic controls for conventional and real-time PCR for the identification of endemic and exotic disease agents. J Virol Methods. 135:229-234.

Soehadji, Setyaningsih H. 1994. The experiences of Indonesia in the control and eradication of foot-and-mouth disease. In: Copland JW, Gleeson LJ, Chamnanpool C, editors. Diagnosis Epidemiol Foot and Mouth Dis Southeast Asia. Proceedings of an International Workshop, Lampang, Thailand, 6-9 September 1993. Canberra (Australia): ACIAR 51:64-69.

Wernery U, Kinne J. 2012. Foot and mouth disease and similar virus infections in camelids: A review. Rev Sci Tech. 31:907-918. 